Udogu, E. Ike. (1999) "Economic Community of West African States: From an Economic Union to a Peace-keeping Mission?” The Review of Black Political Economy, Vol. 26, No. 4 (Spring 1999), pp. 55-74. Springer Verlag (The original publication is available at www.springerlink.com) DOI: 10.1007/s12114-999-1012-5 [ISSN: 1936-4814]

\title{
Economic Community of West African States: From an Economic Union to a Peacekeeping Mission?
}

\author{
E. Ike Udogu
}

\section{Article}

African countries were not part of that great industrial revolution of the eighteenth century that spawned the process of modernization and industrialization in western Europe and North America. [1] Indeed, they were colonies of some of the European powers. As a result, they were sometimes referred to as regimes of delayed industrialization [2] because they only started industrializing following independence. Hitherto, they served fundamentally as the sources for raw materials.

Even after they gained their sovereignty on paper, it was discovered that they still relied heavily on the colonial powers for trade and economic survival. If African countries were to exculpate themselves from what was later termed neocolonialism, by some scholars, it was incumbent upon them to do business with each other. This philosophy was generally attractive and welcomed by some of the political actors who believe that economic sovereignty was a sine qua non for political sovereignty. How might these newly independent nations pursue their objective of continental economic autarky? The initial strategy was the creation of regional economic unions.

So, in East Africa, there was the East African Economic Community. In French-speaking African states, there were a host of economic unions of which L' Organization Commune Africaine et Malagache (OCAM), L'Union Douaniere et Economic de L'Afrique Centrale (UDEAC), and L'Union des Etats d'Afrique Centrale (LTEAC) were some examples. And, in West Africa was created the Economic Community of West African States (ECOWAS). This essay examines the raison d'etre of the ECOWAS, and its contemporary peacekeeping role, against the backdrop of economic crisis in the area. Additionally, it seeks to briefly examine the role of Nigeria, the area's hegemonic power in the peace building enterprise within the context of the republic's foreign policy and national interest. 


\section{ECONOMIC COMMUNITY OF WEST AFRICAN STATES (ECOWAS)}

The widespread trend toward some form of regional economic grouping in both developed and developing countries is no doubt due to growing awareness of the importance of economic interdependence for the promotion of the economic well-being of the peoples of these countries, and for solving and facilitating the solution of some of the knotty economic problems which face individual countries. Even developed countries, which in the 1950s shunned regional integration, have since altered their views and style. For example, the European Coal and Steel community was formed in 1952, and the European Common market in 1957. [3] These were some of the precursors to the modem European Economic Community and European Union.

The United Nations has also encouraged regional integration. Indeed, the Resolution on the "International Development strategy for the second UN development decade, urged developing countries to continue their attempts to put into effect plans for sub-regional and regional development." [4] It has also been recognized that self-reliance and growing cooperation among developing nations will further strengthen their role in the new international economic order.

The beginning of the idea of regional economic grouping in West Africa can be traced back to initiatives emanating from the Economic Commission for Africa. [5] Representatives of the various African countries have held several meetings called by that Commission. For example, there was the Lagos Conference on Industrial Coordination in West Africa in November, 1963; the Niamey Conference on Economic Cooperation in October, 1963; and the Accra Conference of April, 1967, where the article of Association for the establishment of an Economic Community for West Africa was signed. [6]

In 1968, heads of state of the West African group met in Monrovia, Liberia and signed the Protocol establishing the West African Regional group. The only achievement of the group was the preparation by Nigeria and Guinea of priority studies of areas of cooperation. The agreed areas of cooperation were trade, transport, communication, education, cultural exchange and information, research, health, energy, and heavy industries. [7]

A number of attempts made at regional cooperation ended up in fiasco, but these failures did not stop the West African leaders from seeking other means of cooperation. It was to this end that Togo and Nigeria worked assiduously for the creation of regional economic cooperation.

\section{THE BIRTH OF ECOWAS}

The treaty establishing the EGOWAS was signed on May 28, 1975, by fifteen countries. These countries were Dahomey (now the Republic of Benin), the Republic of Gambia, the Republic of Ghana, the Democratic Republic of Guinea, Guinea Bissau, the Republic of Ivory Coast, the Republic of Liberia, the Republic of Mali, the Islamic Republic of Mauritania, the Republic of Niger, the Federal Republic of Nigeria, the Republic of Senegal, the Republic of Sierra Leone, the Republic of Togo, and the Republic of Upper Volta (now Burkina Faso). Cape Verde joined later, and that brought the total membership to sixteen. 


\section{The aims of ECOWAS are stated in Article Two of the treaty of the Community:}

1. It shall be the aim of the Community to promote cooperation and development in all fields of economic activity particularly in the fields of industry, transport, monetary and financial questions and in social and cultural matters for the purpose of raising the standard of living of its peoples, of increasing and maintaining economic stability, of fostering closer relations among its members and of contributing to the progress and development of the African continent.

2. The Community shall by stages ensure:

a. the elimination of custom duties and other similar charges in respect of importation and exportation of goods among Member States;

b. the abolition of quantitative and administrative restrictions on trade among the Member States;

c. the establishment of a common custom tariff and a common commercial policy towards third countries;

d. the abolition as between the Member states of the obstacles to the free movement of persons, services and capital;

e. the harmonization of agricultural policies and the promotion of common projects in the Member States notably in the field of marketing, research and agro-industrial enterprises;

f. the implementation of schemes for the joint development of transport, communication, energy and other infrastructural facilities as well as the evolution of a common policy in these fields;

g. the harmonization of the economic and industrial policies of the Member States and the elimination of disparities in the levels of development of Member States;

h. the harmonization required for the proper functioning of the Community, of the monetary policies of the Member States;

i. the establishment of a fund for cooperation, compensation and development; and

j. Such other activities calculated to further the aims and objectives of the Community as the Member States may from time to time undertake in common. [8]

There exist a number of factors that made it difficult and sometimes impossible for West African states to implement the aims contained in the treaty. Such difficulties and problems have included inadequate infrastructure; road, railway, telecommunications, and other vital links for free movement of goods and persons. There have also been vested desires for the preservation of the existing state of affairs and the persistence of semi-colonial ties, sometimes referred to as neocolonialism, and lack of grassroots involvement. [9] These are the same as the problems that have prevented the realization of African unity at the continental level. 
Other difficulties known to have prevented economic union in West Africa in the past include the small proportion of world trade taking place within the sub-region, the different commercial and financial policies pursued by the countries as a result of their past colonial experience; over dependence of many of the African countries on revenues from Import duties and in some, manipulation of such duties to encourage foreign capital inflow and to protect industries; the existence of different currencies and payment arrangements and competition among them to have visible signs of development even when these are uneconomic.

It is significant to note that the lesson to be learned from these problems and difficulties confronting earlier attempts to bring the West African nations together is that integration is a long term task subject to the uncertainties that characterize many international attempts.

The formation of ECOWAS does not mean an instant solution to the problems confronting the area. It, however, provides the mechanism for combating the problems. One notable issue is that West African countries are mainly primary producers, the agricultural sector employing over 60 percent of the labor force. [10] The member states' products are oriented to the market of developed countries. And until the economies of ECOWAS states undergo structural transformation through which agriculture (as is practiced today) will lose its preponderance to industry, ECOWAS member countries may not significantly be each other's customers. Economic integration under such circumstances is not likely to bring about a sizeable expansion of intra-ECOWAS trade in the immediate future.

Another issue confronting the ECOWAS states is that of common payment, a problem that even the European Union is facing today. West African currencies which are tied to different major international currencies are not all convertible into each other. Article 38 of the ECOWAS treaty provides for creation of a Committee of West African Central Banks which would determine a clearing system of payments for the region. [11] Currency unification would serve as an effective response to the problem of disparate exchange rates within an integrated scheme. It is hoped that under one currency the liberty for capital movement will be improved, and it would also take care of problems of balance of payments in intra-union trade.

Moreover, a major problem that ECOWAS faces is that of determination of location of major industries. Indeed, every country wants industries, since they provide jobs and are believed to enhance modernization. [12]

\section{ECONOMIC AND THEORETICAL RATIONALE FOR ECOWAS}

The theoretical rationale of economic integration in West Africa is generally based on possible ways in which economic integration affects the rate of growth of Gross National Product (GNP) of participating countries. Such economic integration should therefore result in some of the following: 1. Enlargement of the size of the market for firms otherwise producing below optimum capacity. A large market catering for about 130-200 million consumers is also considered significant to sustain heavy industries such as engineering and chemical plants. These would be vehicles for modernization. 2. Economic integration will increase the level of 
economic activity through increased trade, and at the same time allow the exploitation of external economies and inter-industry linkages and also lead to lowering of production cost. 3 . The economic integration envisaged by ECOWAS would lead to economic cooperation, and promotion of economic efficiency through specialization. In short, economic integration would bring about mor e adequate use of resources and harmonization of economic and trade policies among member states.

The significance of developing the infrastructure cannot be over-stressed and remains one of the important objectives of the ECOWAS. And indeed, without an efficient regional transport and communication network, economic integration and later political union would have little meaning.

One of the most important anticipated outcomes of the present economic union of West African States is the eventual continental union which could emerge from such an integration. This dream is reinforced by Article 27 ( 1 and 2) of ECOWAS Treaty, which states that:

Citizens of Member States shall be regarded as Community citizens and accordingly Member States undertake to abolish all obstacles to their freedom of movement and residence within the Community.

Member States shall by agreement with each other exempt Community citizens from holding visitors visas and resident permits and allow them to work and undertake commercial and industrial activities within their territories. [13]

Social intercourse is extremely important in any kind of politico-economic relations. Such intercourse in the past has been mitigated by the problems of visas and, generally, free travel among the various countries. It could be argued that as more Africans travel and meet with other Africans outside their own states, this could kindle a spirit of understanding which is helpful for African unity.

Thus, Article 27 (1 and 2) provides not only the groundwork for economic integration in West Africa, but also a model which is very significant for a future continental union. Optimism was even expressed that ECOWAS working together with other regional groupings could further the 1991 African Economic Treaty aimed at establishing a common market in A..D. 2025. Indeed, it is also hoped that like in Europe, this treaty could lead to the inauguration of an elected African Parliament with a supranational characteristic. [14]

In sum, it is one thing to formulate policies and quite another to implement them. The quest to address the problem of underdevelopment in the sub-region is without doubt very urgent. Unfortunately, it is over two decades now since ECOWAS was created, yet the area has not come close to satisfactorily resolving the fundamental issues contained in its treaty.

To be sure, trade flows between member nations of ECOWAS appear to have increased since the organization's inception. But, contended Mamit Deme, "the volume of trade flows between ECOWAS member countries and industrial countries is proportionately much larger than the intraregional trade flows. For ECOWAS members as a whole, the average annual volume of 
imports from industrialized countries during the 1981-1992 period was US\$13.22 billion. For the same period the average annual volume of imports from African countries was merely US\$1.59 billion, of which US\$1.24 billion is from EGO WAS member countries." [15]

Arguably, the above issue is not based on ECOWAS' lack of efforts; it is based on both internal and external conditionalities. Internally, the area has been faced with numerous civil wars, military coups, and counter coups. Externally, the international lending organizations have made the region completely depend00ent on the creditors, such that a majority of member states of the EGO WAS lack the major elements of sovereignty.[16 The economic misery suffered by the poor in these states is so poignant that a majority of the citizens have been forced to develop antagonistic attitudes toward the state; indeed, they may have in their vexation toward the state "deligitimized" it.

The Human Development Index (HDI), of the 1997 Human Development Report, of the sixteen member states of the ECOWAS is not reassuring against the backdrop of the aims and objectives of the organization. Sierra Leone ranked (175), Niger (173), Burkina Faso (172), Mali (171), Guinea (167), Gambia (165), Guinea Bissau (163), Senegal (160), Mauritania (150), Togo (147), Benin (146), Cote d'Ivoire (145), Nigeria (141), Ghana (132), and Cape Verde (123); Liberia was omitted in the survey because of the civil war in that country. [17] But there were a total of 175 nations measured for this report. The Human Development Index report combines life expectancy, literacy, and distribution of income or basic purchasing power as generally linked with a nation's overall economic prosperity. In short, the "statistics reflect people's well-being and the opportunities that they actually enjoy."'8 its poor economic record so far, why did the group embark upon a risky and unpredictable peacekeeping mission in Liberia? Furthermo re, could this mission signal a shift in its emphasis on economic development in the area to that of peacekeeping in a region that is fraught with ethnic and political problems?

\section{PEACEKEEPING MISSION: A CONCEPTUAL AND THEORETICAL ANALYSIS}

Arguably, peacekeeping attempts predate the modem nation-state system. This is especially so when defined within the context of maintaining international peace and security. It was, however, during the birth of the modern state system that the quest for peace and stability took on an added dimension. This policy was pursued within the framework of a balance of power system. Historically, two major epochs, among others, might illustrate the move toward peace and security in Europe. The first period was from 1648 (the treaty of Westphalia) to 1789 (the French Revolution), commonly referred to as the first golden age of classical balance of power. The second period was from 1815 to 1914 , generally touted the second golden age of classical balance of power.

During the former, religious conflict was reduced, mercantilism was superseded by free trade, and absolute monarchies gradually started to lose their significance to popular sovereignty. Although wars between nation-states persisted, they were of low intensity. [19] The latter saw such powers as England, France, Prussia, Austria-Hungary, and Russia pursue a policy of stable 
and ideologically similar or uniform international politics. [20] This state of relative peace provided opportunities for free movement of people and trade.

Following WWII and in the aftermath of the decolonization process in Africa and elsewhere, the proliferation of independent sovereign states with their distinct and often conflicting national interests created international tensions. Indeed, the character of the post-colonial state in Africa, and the balkanization of Eastern Europe into independent sovereign states following the collapse of communism in that area created severe ethnic strains (for example, the Republic of Georgia), and in some cases irredentist wars (for instance, Bosnia-Herzogovina and Yugoslavia).

The formation of the League of Nations after WWI and its successor, the United Nations after WWII, were intended to ameliorate activities by nation-states that were likely to threaten international peace and security. It was in attempts to avoid the catastrophic consequences of both wars, that the international community, inter alia, encouraged the use of peacekeeping missions when measures such as the use of the good offices of the UN and regional endeavors failed to lead to the pacification of a conflict.

The general strategy of a peacekeeping operation is the interposition of a multinational force between combatants to provide the enabling environment for peaceful resolution of a political dispute. In this regard, the views propounded by the International Peace Academy in the early 1 980s is instructive and approximates the overall mechanism of the process, viz: "the prevention, containment, moderation and termination of hostilities between or within states through the medium of third-party intervention organized and directed internationally, using multinational military, police, and civilian personnel to restore and maintain peace." [21]

The activities of the UN in the area of peacekeeping, peace making, and peace enforcement have been daunting. Indeed, it has had its successes and failures in Central America, the Middle East, Asia, and elsewhere. The intensification of the peacekeeping role of the UN appears to have gathered momentum following the end of the Cold War. Indeed, soft states that were pawns in the superpower rivalry and the politics of the zero-sum-game, were now free to exercise their right to national self-determination. The consequences were disastrous for such1 dependencies as Mozambique, Zaire, Angola, Ethiopia, and others. In fact, of the thirty-eight peacekeeping missions sponsored by the United Nations since its inception in 1945, twenty-five were put into force between 1988 and 1995. [22]

Moreover, with the emergence of the "new international world order," the political calculus within the UN as to its strategy for handling conflicts had to be adjusted in accordance with contemporary realism--i.e, the collapse of communism in the Soviet Union. This demise, in the thinking of many observers, not only signaled the victory of democracy over communism, but also illustrated its superiority. With the Russian Federation, the major remnant following the implosion of the former USSR, now a full fledged member of the democratic club in the UN, and with the wind of change and euphoria of political liberalization blowing across Africa and elsewhere, the UN was "compelled" to assume two non-traditional roles. The first was the enforcement of peace, such as in Yugoslavia and Somalia, and the second was to take on the role of an instrument for democratic transition. [23] The latter was designed to build and promote the conditionalities for the sustenance of democracy and peace. This philosophy was propagate $d$ in 
1992 by the erstwhile Secretary-General Boutros Boutros-Ghali who termed this genre of UN peacekeeping strategy in his Agenda for Peace, Postconflict Peace Building.24

In Africa, UN peacekeeping missions have taken on different forms because of the complexities of the political issues in the area. For instance, in Angola and Mozambique, it took on the onerous task of implementing political as well as democratic transitions. In Namibia, it conducted elections to establish an independent state of Namibia, and is presently preparing Western Sahara for a national referendum intended to lead to the area's independence from Morocco.

In sum, with all its good intentions, the UN is generally plagued with a number of contradictions-rooted in its axioms of sovereignty, neutrality, and attaining democratic peace. To compound the organization's problems is the fact that UN agents are often confronted with both international and indigenous obstacles, as for example, Somalia, that sometimes render their missions impossible. The situation in Liberia falls within this framework, and hence the allurement for a regional solution to a common problem in the continent.

\section{THE LIBERIAN CRISIS}

The frequency of civil wars in the continent is commonplace due to economic and ethnopolitical crisis. The sometimes overt and covert involvement of African states in the internal affairs of countries experiencing such wars, in contravention of Article 2, paragraph 4 of the UN charter, which forbids member nations of the UN from doing so, is not novel. In West Africa, though, the collective action of member states of the Economic Community of West African States (ECOWAS) in the Liberian political crisis was unique. This was so because provisions were not made in the ECOWAS treaty for a military action to bring about peace to a member state. To be sure, African countries have been involved in peacekeeping efforts, but these were carried out under the auspices of the United Nations which has the infrastructure for such an undertaking. Witness for example, the UN peacekeeping operation in the Suez Canal in 1956 to resolve the British, Israeli, and Egyptian crisis, and the Congo issue of 1960. [25] Moreover, suc h actions were generally implemented on an ad hoc basis to tackle conflicts that were construed to be a threat to international peace and security.

It is true that such regional organizations as the Organization of American States (OAS) has been successful at regional peace operations in the Americas. The OAS operated in the Dominican republic in 1965 and more recently in Haiti to restore democracy. In these operations, the United States remained the hegemonic power and generally acted on the basis of her national interest, and within the context of the Monroe doctrine, which places the area within the sphere of its influence. In Africa, however, no regional organization has ever taken a peacekeeping mission before ECOWAS interloped in Liberia. [26]

The major regional power in the region and ECOWAS itself is Nigeria, which like any other regional hegemon, tends to equate its national interest with that of the group. Nigeria became the major dramatis personae in the Liberian political saga, when it created ECOWAS Cease-fire 
Monitoring Group, whose acronym was ECOMOG. Despite initial opposition within its ranks spearheaded by Cote d'Ivoire and Burkina Faso, ECOMOG pursued with resiliency its twin objectives of making and enforcing peace. [27] The following discussion centers on Nigeria, whose participation was paramount for the successful conclusion of the mission.

\section{NIGERIA AND ECOMOG}

There are two possible contending theories, or schools of thought, regarding Nigeria's involvement and leadership in the operation. Scholars of the first school argue that the internal political dynamics in the country accounted for Nigeria's active participation in the peace mission, especially since such matters are generally within the purview of the United Nations. The second school stresses the importance of Nigeria in the region and the centrality of its foreign policy in West Africa in particular, and Africa in general.

According to the first school, President Babangida's transition program to a democratic rule in Nigeria from 1989-1993 appeared to be going nowhere. Primary elections were canceled and rescheduled. Babangida and his administration's ability to dribble the political entrepreneurs and society "maradonically," by the late 80 s and early 90 s had created profound anxiety and frustration, particularly, among members of the informed public and the media. Indeed, the general opinion in the country regarding the transition program was that it was a farce, if not a ruse. They contended that despite the administration's timetable for handing over power to a democratically elected politicians, Babangida had his own "hidden" agenda. The print medium and others who belonged to this school were relentless in their criticism of the administration on this score. They insisted that Nigeria's profound involvement in ECOMOG was intended to divert the people's attention from the political blunders at home. They argued, that the a ssumption on the part of the regime was, that Nigerians would rally behind their government at a time of crisis involving a preponderant number of Nigerian soldiers. Within this school, moreover, were those who contended that, Babangida, having survived a military coup, wanted to keep the soldiers busy by sending the possible "trouble" makers in the military away from Lagos and Abuja. In this way, they would be less likely to foment another coup in light of the internal political dislocation and unsteadiness.

The second school of thought which I shall term the national interest school, attempts to explain Nigeria's activities in the ECOWAS and ECOMOG within the context of Nigerian foreign policy. It is on the assumptions of this school that I will focus my succeeding analysis.

\section{ECOMOG AND THE NATIONAL INTEREST SCHOOL}

The ethnically induced civil war in Liberia between the Americo-Liberian and the indigenous population which was triggered following sergeant Samuel Doe's coup d'etat of April 1980 had reached its crescendo by the late 1980s. The activities of Charles Taylor and his National Patriotic Front of Liberia (NPFL) and the other forces were causing casualties both in human life 
and property. The refugee problem was taxing the resources of the neighboring countries. [28] Furthermore, in the carnage, foreign nationals became a pawn in the civil war. For whatever tactical reasons, Nigerian citizens living in Liberia became the major bete noire and target for NPLF's retribution. [29] Arguably, Nigeria's prestige as the hegemon in the area and harassment of its citizens living in Liberia, the political instability in Sierra Leone, the refugee problems in the neighboring countries, and the possible domino-effect of the civil war in the region served as the rationales for Nigeria's military putsch in Liberia--a mission wh ich General Sani Abacha claimed cost the Nigerian government over US\$3 billion. [30]

Theoretically, a hegemon assumes a leadership stance in a community of nations for the purpose of expanding its power, influence, authority, and control in order to obtain greater economic and security advantage. [31] Within this context, it seeks a policy of expansionism through economic, political, and military control. A hegemonic power tends to succeed in its endeavor because of its overbearing and sometimes intimidating presence. Such an imposing stature is furthered by its ability to provide goods and services that are needed by the "lesser" and weaker states. Indeed, Pax Britannica and Pax Americana have been cited as examples of hegemonic states enforcing peace and security on the international scene and system as a strategy to promote the interest of the hegemonic state. [32] Today, in the political conversation in West Africa and Nigeria in particular, there is already talk of Pax Nigeriana [33] in the wake of Nigeria's successful performance in the Liberian crisis. In fact, with a population of $80--100$ million, a GDP of $\$ 30$ billion and a strong military to match, Nigeria is on course to pursue its interest in the region.

In order to pursue its foreign policy objectives within the African and regional context, [34] Nigeria invoked the tenets of Chapter VIII, Article 52 of the charter of the United Nations on Regional Arrangements. In this way, ECOMOG was able to receive support from the international community, because its actions could not be misconstrued as usurping the powers of the Security Council under Article 34 and 35. [35]

\section{Indeed, Article 52 states:}

1. Nothing in the present Charter precludes the existence of regional arrangements or agencies for dealing with such matters relating to the maintenance of international peace and security as are appropriate for regional action, provided that such arrangements or agencies and their activities are consistent with the Purposes and Principles of the United Nations.

2. The Members of the United Nations entering into such arrangements or constituting such agencies shall make every effort to achieve pacific settlement of local disputes through such regional arrangements or by such regional agencies before referring them to the Security Council.

3. The Security Council shall encourage the development of pacific settlement of local disputes through such regional agencies either on the initiative of the states concerned or by reference from the Security Council [ldots] [36] 
Having cleared the above hurdle, as it were, Nigeria was now prepared to pursue its foreign policy interest within the framework of ECOMOG. To this end, President Babangida declared:

We are in Liberia because events in that country have led to massive destruction of property, the massacre by all parties of thousands of innocent civilians including foreign nationals, women, and children, some of whom have sought sanctuary in the churches, mosques, diplomatic missions, hospitals, and under Red Cross protection contrary to all recognized standards of civilized behavior and international ethics and decorum. [37]

Although the above assertion represented the official view of the administration, there may be two other remote causes for Nigeria's reaction to the Liberian upheaval. First, the war was affecting Nigeria's economic interest (both governmental and non-governmental). Second, the Samuel Doe regime was friendly to the Babangida Administration, and Babangida, for his own personal interest, did not want to see a friendly government replaced by a hostile one--e., Charles Taylor. After all, Nigeria established the Ibrahim Babangida School of Political Science and Strategic Studies in Monrovia for a cost of US\$20 million in appreciation of the cordial relations between both governments. [38] Furthermore, Nigeria was concerned that if Taylor was allowed to succeed, he might foment trouble in Gambia, Guinea, and Sierra Leone, countries that were considered friendly to Nigeria.

Economically, and because of its share size and wealth in the region, Nigeria's export to member nations of ECOWAS is substantial. However, it is difficult to observe the effect of economic growth in intra-ECOWAS trade in the overall well-being of the citizens of member states. In fact, Mamit Deme in his study discovered that "imports from industrialized countries by Nigeria, Cote d'Ivoire, Liberia, Ghana and Senegal on the average grew (or decreased) by $-3 \%,-1 \%, 24 \%$, $6 \%$ and $-2 \%$, while those from ECOWAS partner countries grew by $8 \%, 14 \%, 22 \%, 3 \%$, and 5\%." [39] These figures are represented in Table 1.

The figures presented below represent business flows at the official level. The volume of trade between private citizens at the informal level that are unaccounted for, is phenomenal. This involves the underground economic intercourse which is rampant in the region. [40] Also, the table shows that the ECOWAS still spend more for goods and services from Western Europe.

Nigeria created the ECOWAS because it was in her interest, realist scholars would argue. Economically, too, political instability in the area could not further its interest of economic integration and mutual cooperation. [41] In fact, the desire for regional stability has always been a major objective of the various Nigerian regimes from Prime Minister Sir Abubakar Tafawa Balewa to General Sani Abacha. For example, General Yakubu Gowon who was a signatory to the ECOWAS treaty in 1975 observed that such a grouping was likely to mitigate the role of France among Francophone West African states. Economic health in the area could promote political security and the protection of Nigerian borders. [42] General Olusegun Obasanjo also noted that Nigerian foreign policy objective included the establishment of the desired political and economic conditions in the area to promote Nigeria's economic development. [43] President Babangida summed up Nigeria's interest thus: "When certain events occur in this subregion...which are bound to affect Nigeria's politico-military and socio-economic environment we should not stand by as helpless and hapless spectators." [44] 
Moreover, the fact that the internal economic dynamics of a nation-state tends to influence foreign policy decisions is illustrated in the concern and pressures from multinational corporations who stand to lose a lot of money in unhealthy political climates. For example, Cadbury Nigeria Limited, one of several major corporations doing business within the ECOWAS member states brought pressure to bear on the Nigerian government to create an enabling environment in Liberia for it to do business. Indeed, Margaret Vogt wrote: "The Managing Director of Cadbury Nigeria Limited [a confection company] stated that his company had lost over $\mathrm{N} \$ 10$ million in export proceeds since the beginning of the Liberian crisis. If this was true for Cadbury, it was bound to be true for other Nigerian companies doing business with Liberia..." [45]

Another area of concern to Nigeria in her foreign policy and ultimate participation in the peacekeeping effort in Liberia relates to its claim that West Africa is within her sphere of influence--a sort of "Nigerian Monroe doctrine." The interference of Libya, United States, France, and other external powers in Liberia was considered to be inimical to the overall interest of Nigeria. The United States and France aside, Libya, Nigeria's political nemesis in Chad, was known to be supplying arms and ammunition to Charles Taylor's NPLF. Such successful "external" encroachment was bound to create the impression that Nigeria was not only weak, but also unable to resolve a political crisis in her "backyard." Nigeria's failure to act in Liberia might further the notion that Nigeria was only a "paper tiger" in the region. Faced with these circumstances, as it were, Nigeria was determined to do whatever it took to bring peace to Liberia even in the light of mounting criticisms at the home front and billions of nairas $i \mathrm{t}$ had spent on the operation.

\section{END OF THE WAR}

The general assumption, noted Eva Bertram, is that peace building attempts tend to share certain fundamental characteristics: 1 . they deal with conflicts within rather than between states; 2 . the host government is one of the parties to the conflict; 3. their aim is to develop and/ or implement a political transition following or accompanying an end to military hostilities; and 4. a central component is the reform or establishment of basic state institutions. [46] Retrospectively, the development in Liberia followed the above chronological order.

Indeed, the painstaking efforts toward peace came to fruition as a result of a series of complex negotiations in which Nigeria as the leader of ECOMOG played a major role. The formation of an interim legislative body, and the multiparty elections that followed culminating in the victory of Charles Ghankay Taylor were some of the important, yet occasionally problematic, steps undertaken by ECOMOG. On August 2, 1997, at the swearing-in ceremony of Taylor as the twenty-first President of the Republic of Liberia, General Sani Abacha, current chairman of ECOWAS, said:

Indeed, as we look back on the many attempts at finding peace for Liberia, the victory which we celebrate becomes even more precious and uplifting. The catalogue of all those conferences which resulted in so many peace accords from Banjul in 1990 to Yamousoukro--a series of talks, 
from Geneva to Cotonou and then Akosombo to Accra should remind us how difficult and fraught with frustration and even [how dangerous] this whole process had been. The Abuja agreement of 1995 and its Revised Schedule of implementation of August, 1996, were a culmination of all these efforts. [47]

It goes without saying that the ECOWAS intervention in Liberia under the auspices of ECOMOG is epochal in spite of the antinomies and intermittent political, diplomatic, and military setbacks. This is even more so because unlike the UN, ECOMOG lacked both the structural and institutional mechanisms for peacekeeping. Yet, when push came to shove, the group, despite members limitations and contradictory national interests, the complexities of the ethnic character of the civil war itself, succeeded in this important mission. It must be noted, though, that the outcome of the operation would have been more difficult were it not for the support of the United Nations. To this end, it could be argued that such a regional attempt at solving regional problems, with the assistance of the international community, might become a model in the "New International World Order."

\section{LOOKING AHEAD}

If there was any lesson to be learned from the Liberian crisis, it might be to remind ourselves of one of Sir Winston Churchill's dicta regarding wars when he said: "It is easy to start a war, but difficult to end one." This view was echoed by General Sani Abacha at the inauguration of Charles Taylor when he affirmed: "... if the difficulties we have encountered teach any lessons, it is that wars, especially civil wars, are easy to ignite on the raw emotions of ethnic chauvinism, but difficult to stop, even when our instincts of nationalism finally compel us to draw back from the brink." [48] In spite of these words of wisdom, ECOMOG is poised to undertake a somewhat similar mission in Sierra Leone following the military coup of Major Johnny P. Koroma on May 25, 1997, that toppled the regime of President Ahmad Tejan Kabbah.

Whatever might become of the Sierra Leonean operation, ECOWAS must not become oblivious to the fundamental objectives of economic growth and solvency in the region. It is true that civil wars tend to affect the flow of trade, but ethnically motivated crisis and political instability in the sub-region issue from the problems of underdevelopment and scarce resources. Indeed, it is the competition for the meager resources in the area that, inter alia, trigger ethnic and racial conflicts in Africa.

ECOWAS was not created as a war machine; it was established as an economic union for the purpose of assailing the intractable condition of poverty existing in this region. [49] While ECOWAS/ECOMOG deservedly celebrates its triumph in Liberia and now attempts to plunge itself into the Sierra Leonean imbroglio, it must also be prepared to pursue its policy of economic revival with equal, if not more, vigor than the peace efforts in Liberia. In this way, ECOWAS would not be placing the cart before the horse. Normatively, too, as the area marches toward the next millennium, it should be noted that economic revitalization is a sine qua non for peace and stability. Indeed, it is only when member states of the ECOWAS pursue vigorously the tenets of 
its treaty within the context of liberalization and democracy that the area might be spared of the crisis that engulfed Liberia and now rages in Sierra Leone.

\section{NOTES}

(1.) E. Ike Udogu, "The Issues of Development and Environment in Africa: An Overview," in Rukhsana A. Siddiqui (ed.) Sub-Saharan Africa in the 1990s: Challenges to Democracy and Development (Westport, CT: Praeger, 1997), p. 189.

(2.) Mary Matossian, "Ideologies of Delayed Industrialization: Some Tensions and Ambiguities," Economic Development and Cultural Change, Vol. 6 (1958), pp. 217-218.

(3.) Emmanuel I. Udogu, The Problems of African Unity and the Awakening of Regional Cooperation (Carbondale, IL: MA Thesis, Southern Illinois University, 1977), p. 89.

(4.) Economic Community of West African States (FGP 1936/(75)176/25,000), p. 12.

(5.) Ibid., p. 4.

(6.) Ibid.

(7.) Udogu, The Problems of African Unity and the Awakening of Regional Cooperation, p. 90.

(8.) Treaty of the Economic Community of West African States (New York: Nigerian Consulate, 1975), pp. 7-8.

(9.) Mamit Deme, "The Impact of ECOWAS on Intraregional Trade Flows: An Empirical Investigation," The Review of Black Political Economy, Vol. 23, No. 3 (Winter 1995), p. 116

(10.) Uke Ezenwe, "The way ahead for ECOWAS: Two," West Africa, (27 September, 1976), p. 1043.

(11.) Treaty of the Economic Community of West African States, p. 29.

(12.) Udogu, "The Issues of Development and Environment in Africa: An Overview," in Siddiqui (ed.), Sub-Saharan Africa in the 1990s: Challenges to Democracy and Development, pp. 192-194.

(13.) Economic Community of West African States, p. 8

(14.) Julius O. Ihonvbere, "Evolving sovereignty in an interdependent world: The challenge of democratization in sub-Saharan Africa," International Politics (formerly Coexistence), Vol. 33, (September 1996), p. 264. 
(15.) Deme, op. cit., pp. 117-118

(16.) Ihonvbere, op. cit., pp. 245-267.

(17.) Human Development Report 1997: United Nations Development Programme (New York: Oxford University Press, 1997), pp. 142-147.

(18.) Ibid., p. 143.

(19.) Theodore A. Columbus and James H. Wolfe, Introduction to International Relations: Power and Justice (Englewood Cliffs, NJ: Prentice-Hall, 1990), p. 44.

(20.) Ibid.

(21.) International Peace Academy, Peacekeeper's Handbook (New York, 1984), p. 7.

(22.) Eva Bertram, "Reinventing Governments: The Promise and Perils of United Nations Peace Building," Journal of Conflict Resolution, Vol. 39, No. 3 (September 1995), p. 388.

(23.) Ibid.

(24.) Cited in Ibid.

(25.) Ademola Adeleke, "The Politics and Diplomacy of Peacekeeping in West Africa: The ECOWAS Operation in Liberia," The Journal of Modern African Studies, Vol. 33, No. 4 (1995), pp. 570-571.

(26.) Ibid., p. 571.

(27.) Ibid., p. 569.

(28.) Toyin Falola, "Nigeria in the Global Context of Refugees: Historical and Comparative Perspective," Journal of Asian and African Studies, Vol. XXX11, No. 1-2 (June 1997), pp. 5-6.

(29.) Terry Mays, "Nigerian Foreign Policy and the Liberian Civil War," A paper presented at the annual meeting of the South Carolina Political Science Association, Clemson University, (March 29, 1994), pp. 4-6.

(30.) "President Sani Abacha's Speech Delivered at the Inaugural Ceremony of President Charles Ghankay Taylor," The [Liberian] INQUIRER, (Tuesday, August 5, 1997), p. 6

(31.) Robert Gilpin, War and Change in World Politics (New York: Cambridge University Press, 1981), pp. 29, 145.

(32.) Ibid. 
(33.) "Nigeria's Fourth Republic looms," West Africa, No. 4168 (29 September-5 October 1997), p. 1528.

(34.) Julius O. Ihonvbere, Nigeria: The Politics of Adjustment \& Democracy (New Brunswick, NJ: Transaction Publishers, 1994), pp. 35-71.

(35.) Article 34 states that: The Security Council may investigate any dispute, or any situation which might lead to international friction or give rise to dispute, in order to determine whether the continuance of the dispute or situation is likely to endanger the maintenance of international peace and security.

Article 35 affirms that: Any Member of the United Nations may bring any dispute, or any situation of the nature referred to in Article 34, to the attention of the Security Council or of the General Assembly.

(36.) Robert E. Riggs and Jack C. Plano, The United Nations: International Organization and World Politics (Chicago, Ill.: The Dorsey Press, 1988), p. 377.

(37.) "Taylor Rejects Bamako Initiative," West Africa, (November 12-18, 1990), p. 2836.

(38.) Adeleke, op. cit., p. 578.

(39.) Deme, op. cit., pp. 118-119.

(40). Zaki Ergas, "In Search of Development: Some Directions for Further Investigation," The Journal of Modern African Studies, Vol. 24, No. 2 (1986), pp. 305-312.

(41.) Emenike Okorie, Yakubu Mohammed and Abdulrazaq Magaji, "Celebration of Wishes," Newswatch, Vol. 14, No. 3 (July 15, 1991), p. 20.

(42.) Alajide Aluko, Essays on Nigerian Foreign Policy (London: George Allen and Unwin, 1981), p. 13.

(43.) Alaba Ogunsanwo, The Nigerian Military and Foreign Policy 1975-1979: Processes, Principles, Performance, and Contradictions, (Princeton, NJ: Princeton University Press, 1980), p. 16.

(44.) Nigeria and the ECOWAS since 1985, (Enugu: Fourth Dimension Publishing Co., and the Nigerian Institute of International Affairs, 1991), p. 104.

(45.) Mays, op.cit., p. 13.

(46.) Bertram, op.cit., p. 388.

(47.) "President Sani Abacha' s Speech Delivered at the Inaugural Ceremony of President Charles Ghankay Taylor," op.cit., p. 6. For a superb discussion of the intricacies of the operation, 
see Carolyn M. Shaw and Julius O. Ihonvbere, "Hegemonic Participation in Peace-Keeping Operations: The Case of Nigeria and ECOMOG," International Journal on World Peace, Vol. XIII, No. 2 (June 1996), pp. 31-60; George Klay Kieh, "Combatants, Patrons, Peacemakers, and the Liberian Civil Conflict," Studies in Conflict and Terrorism, (April/June 1992), pp. 131-132.

(48.) Ibid., pp. 6-7

(49.) M. N. Ogbonna and Abraham E. Nwankwo, "A Dynamic View of Dependency Within Integration: The Case of Ecowas," African Studies, Vol. 10 (January 1986), p. 186. 